\title{
EVALUATION OF THE CLINICAL EFFICACY OF THREE MEDICATIONS USED FOR TREATMENT OF EARMITE-INDUCED OTITIS EXTERNA IN CATS: A PRELIMINARY STUDY
}

\author{
M.I. HAMED*; R.K. SAYED ${ }^{* * *}$ and N.E. WALY** \\ ${ }^{*}$ Division of Infectious Diseases \\ ${ }_{* * * *}^{* *}$ Division of Internal Veterinary Medicine, Animal Medicine Department \\ **** Veterinary Teaching Hospital, Faculty of Veterinary Medicine, Assiut University, Assiut 71526, Egypt. \\ Email: mahohzero@gmail.com
}

\section{ABSTRACT}

Received at: 1/10/2014

| Accepted: $\underline{21 / 10 / 2014}$

\begin{abstract}
The aim of this study was to compare the clinical outcome of three different medications (ivermectin injection, canaural eardrops and frontline combo) in treatment of ear mite infestation accompanied by otitis externa in cats using a randomized trial. Cases presented to the Small Animal Clinic, Faculty of Veterinary Medicine, Assiut University for investigating signs of ear mite infestation and/or otitis externa were recruited $(n=17)$ and randomly assigned to one of the 3 groups for evaluation of response to treatment over a period of 30 days. Cases that did not respond to treatment within 2 weeks of treatment were changed to one of the other two medication. A simple questionnaire was designed to evaluate owner satisfaction of the medication price, ease of administration, cat tolerance and improvement of signs. Recruited cases were either brought to the clinic for re-evaluation or the owner was contacted by phone to evaluate progress of each case. In the ivermectin-treated group (Group 1; $n=7$ ), $75 \%$ of cases recovered from ear mite infestation based on signs resolving and disappearance of presenting signs. Only $60 \%$ of cases treated with frontline (Group 2 ) showed an improvement of signs $(\mathrm{n}=5)$. All cases treated with Canaural (Group 3) showed complete recovery with complete absence of presenting signs and signs of otitis externa $(n=5)$. Average age of cats in all groups ranged from two to 72 months $($ mean $=17.33$, median $=6.5)$. - Statistically there were no significant difference between the three medications ( $p>0.5$ ), but according to the clinical findings, we can suggest that Canaural is the most suitable when otitis externa is present along with ear mite infestation. Frontline Combo is not as effective as the two other medications used in this study.
\end{abstract}

Formatted: Centered

\section{Formatted: Font: Not Bold,} Complex Script Font: Not Bold

\section{INTRODUCTION}

Ear mites-induced otitis externa are the most common ear problems in cats and, less commonly, in dogs. Otodectes cyanotis, the ear mite is the most common mange mite of dogs and cats with prevalence ranging from 20 to $45 \%$ in cats; it feeds on tissue debris and secretions from the ear canal lining, lymph, and blood causing intense itching (Urquhart et al., 1996 and Roy et al., 2011). Severe trauma to the infected area may results when cats scratch the irritated skin. Signs of ear mite infestation may include head shaking and ear scratching (Van den Broek and Thoday 1994). Dark granular substance is often will be present in the ear canal of a cat with ear mites, and signs of irritation and itchiness will be evident. This debris, caused by mite waste products, cerumen, dead tissue and fluid, resembles dark coffee grounds like substance (Degiorgis et al., 2001 and Scott et al., 2001). The mites can also crawl to other parts of the body and cause itching. In chronic cases of ear mites in cats and dogs, there is often secondary bacterial and yeast infections present that complicate the treatment and create even more stress on the animal (Wills and Wolf, 1993 and Gotthelf, 2000). On otoscopic examination, the mites can be seen as white insects crawling on the surface of the exudates. A roll smear is a useful technique for diagnosing ear mite infection when mites are not seen otoscopically (Degiorgis et al., 2001).

Causes of otitis externa are divided into predisposing factors, primary causes and perpetuating causes. Primary causes of otitis externa include parasites such 
Assiut Vet. Med. J. Vol. 61 No. 144 January 2015

as, Otodectes cynotis (ear mite), Demodex canis, Otobius megnini (spinous ear tick), Sarcoptes scabiei, Notoedres cati, Cheyletiella spp, and Eutrombicula spp (chiggers), foreign bodies, hypersensitivity and allergic diseases keratinization disorders and autoimmune diseases (Rosser, 2004).

There are several medications available for treatment of ear mites. Some contain miticide only; others will have antibiotics and/or a medication to help break down of wax and debris (Wills and Wolf, 1993). Otoacariosis can be treated by multiple instillation of an otic preparation or by a systemic treatment with ivermectin or with a topical treatment with fipronil (Chauve, 1984; Carlotti, 1991; Coleman and Atwell, 1999). A recent study compared two topical remedies in treating otitis externa in cats (Germain et al. 2008). In our study, we compare three medications including one systemic and two topical treatments of ear mite infestation and otitis externa in cats.

Ear mite infestation represents a considerable problem in Egypt. In a previous report, more than $59 \%$ of otitis cases presented between years 2007 2011were due to ear mite infestation (Waly and Khallaf, 2013).

Therefore, this study was designed to evaluate three most commonly used medications (ivermectin, fipronil and an otic preparation) for treatment of ear mites in cats. Owner compliance, satisfaction to the method of administration and the improvement of signs was also evaluated.

\section{MATERIALS and METHODS}

\section{Recruitment of cases:}

A total of 17 client-owned cats were recruited to the study. Cats admitted to the Small Animal Clinic, Veterinary Teaching Hospital at Assiut University were included on fulfilling a set of inclusion criteria The inclusion criteria for the trial were set as follows, (1) Cats presented with signs suggestive of ear mite infestation (coffee ground earwax, itching, injuries and loss of hair around the ear, signs of pain during and after examination, head-shaking and abnormally held ear pinnae).

(2) Visualization the ear mites using an otoscope to confirm diagnosis.

(3) Owner's consent to inclusion in the trial.

\section{Clinical investigation:}

A full case history and a full physical examination of each cat was performed in the first visit by one of the clinicians (R. Kamel or N.E.Waly). Otoscopic examination was performed to confirm presence of otitis and ear mite infestation.

\section{Study protocol:}

Recruited cases $(n=17)$ were randomly assigned to one of the 3 groups for evaluation of response to treatment over a period of 30 days. Cases that did not respond to the assigned medications were changed to one of the other medications (Fig1). The cases were randomized to the three treatment groups. Following confirmation of the diagnosis, the severity of infestation was determined using an evaluation sheet (Fig 3) for the case before treatment, and according to that sheet, the cases classified as mild, moderate, or severe cases. Then cats were assigned to one of the treatment groups and the owner was given the feedback and follow-up sheets (Fig 2).

The follow-up sheet was designed to record response to treatment and owner satisfaction on a weekly basis for 4 weeks (Fig 2). Each criterion in this sheet was presented on a visual analogue scale (VAS) and assigned a score from 0 to 10 , where zero corresponded to "no response to medication", and 10 corresponded to "complete recovery". At each assessment, the external ear canals and/or aural canal debris from both ears were examined for the presence of live ear mites. Each animal was also assessed for the presence of each of six clinical signs consistent with $O$. cynotis infestation: head shaking, pruritus/ear scratching, trauma or alopecia of the pinnae and erythema of, ulceration of, and debris in the ear canals. Each sign was assessed as being either absent, mild, moderate or severe (Fig 3).

\section{Protocol of medications:}

- Group 1: All cases in this group received ivermectin (Noromectin®, Norbrook 1254-94) by subcutaneous injection for 2 to 4 times with oneweek interval.

- Group 2: All cases in this group received Fipronil (Frontline Combo, Merial D41704AL) by application of the drug directly on the skin and repeated after one month.

- Group 3: All cases in this group received topical application of an Otic preparation (Canaural ${ }^{\circ}$, VetXX 022153-01) twice daily for 21 days following the manufacturer's guidelines.

\section{Statistical Analysis}

The mean, median, minimum and maximum were used to describe the quantitative variables, frequency and percentage were used to describe qualitative or ordering variables.

\section{RESULTS}

\section{Signalment:}

There were only two breeds presented to the clinic that fulfilled the inclusion criteria; these were Persian $(n=10)$ and Angora $(n=7)$. Nine out of 17 cats were entire males and the remaining Eight were females 
(Table 1). The age of investigated cats ranged from two to 72 months with an average of 17.33 and a median of 6.5 (Table 3). Group 1 were two female Angora (7-12 months), one female and two male Persian (2-6 months). Group 2 were two female and one male Persian (2- 12 months), one female and one male Angora (4-12 months). Group 3 were two female and one male Angora (2- 72 months) and four male Persian (3- 14 months).

Seven cats showed signs of mild ear mite infestation in the form of mild itching at long intervals, presence of little amount of earwax, which is not dark in color Six cats showed signs of moderate infestation with ear mite which expressed by presence of dark colored earwax covering the ear canal, itching at short intervals, loss of hair around the ear and pain during examination. Four cats showed signs of severe ear mite infestation which expressed by presence of large amount of dark colored earwax, severe itching, loss of hair and injuries around the ear, shaking of head and dropping of the ear during and after the examination. Breakdown of cases according to severity of sings in each treatment group are shown in table 2. Two cats showed mild infestation with ear mite, three cats showed moderate infestation and two cats showed severe infestation in Group 1 . Meanwhile, group 2 there were only two cats showed mild infestation and three cats showed moderate infestation with ear mite. Finally, group 3 there were three cats with signs of mild infestation and two cats with severe ear mite infestation.

\section{Response to treatment:}

Total responded cases to total non-responded case was 16 to 1 (Figure 4). $75 \%$ of cases in the first group responded very well to treatment. Only $60 \%$ of cats in the second group responded to the treatment, the remaining $40 \%$ were changed to receive one of the two other medications. All cats in the third group showed complete recovery (Table 4, Figure 5).

\section{Owner satisfaction with the used drug:}

$85.71 \%$ of owners of group 1 were satisfied with the clinical improvement of their pet meanwhile $71.43 \%$ of them were satisfied with ease of administration of the drug. $100 \%$ of owners were satisfied with the ease of administration of the drug in group 2; however, only $80 \%$ of owners was satisfied with the clinical improvement of their pet. $80 \%$ of owners were satisfied with the clinical improvement of their pet; meanwhile $40 \%$ of the owners complained from the difficulty of administering the drug in group 3 and found it hard to comply with the instructions. No owners complained from the cost of medication in all treatment groups (Figure 6).

The difference between the three used medications was not statistically significant $(\mathrm{p}=0.409)$

Table 1: A breakdown of sex and breed in each treatment group

\begin{tabular}{cccccc}
\hline & \multicolumn{2}{c}{ Sex } & \multicolumn{2}{c}{ Breed } \\
\cline { 2 - 6 } & male & female & Persian & Angora \\
\hline Group 1 & 5 & 2 & 4 & 3 \\
\hline Group 2 & 2 & 3 & 3 & 2 \\
\hline Group 3 & 2 & 3 & 3 & 2 \\
\hline
\end{tabular}

Data represents number of animals.

Table 2: A breakdown of severity of infestation in each treatment group

\begin{tabular}{cccc}
\hline & \multicolumn{3}{c}{ Severity of signs } \\
\cline { 2 - 4 } & Mild & moderate & Severe \\
\hline Group 1 & 2 & 3 & 2 \\
\hline Group 2 & 2 & 3 & 0 \\
\hline Group 3 & 3 & 0 & 2 \\
\hline
\end{tabular}

Distribution of cases according to the severity of infestation signs in each treatment group.

Table 3: Age statistics of recruited cases in each treatment group

\begin{tabular}{ccccc}
\hline Treatment group & Minimum & Maximum & Mean & Median \\
\hline Group 1 & 2 & 72 & 17.33333 & 6.5 \\
\hline Group 2 & 2 & 12 & 3 & 4 \\
\hline Group 3 & 2 & 12 & 9.5 & 9.5 \\
\hline
\end{tabular}

Statistical analysis of age distribution in each treatment group, age presented in months. 
Formatted: Font: $10 \mathrm{pt}$, Complex Script Font: $10 \mathrm{pt}$

Formatted: Font: 12 pt, Bold Complex Script Font: 12 pt, Bold Formatted: Font: 12 pt, Bold, Complex Script Font: 12 pt, Bold
Assiut Vet. Med. J. Vol. 61 No. 144 January 2015

Table 4: Outcome of use of medications in all groups

\begin{tabular}{c|c|c|c}
\hline & $\begin{array}{c}\text { Group 1 } \\
\text { (Ivermectin) }\end{array}$ & $\begin{array}{c}\text { Group 2 } \\
\text { (Frontline) }\end{array}$ & $\begin{array}{c}\text { Group 3 } \\
\text { (Canaural) }\end{array}$ \\
\hline Recruited & 7 & 5 & 5 \\
\hline Recovered & 5 & 3 & 5 \\
\hline $\begin{array}{c}\text { Unresponsive } \\
\text { Switched to } \\
\text { other medication }\end{array}$ & 2 & 2 & 0 \\
\hline $\begin{array}{c}\text { (changed to } \\
\text { canaural) }\end{array}$ & $\begin{array}{c}\text { (changed to } \\
\text { ivermectin) }\end{array}$ & \\
\hline metal recruited cases after changing & 8 & 5 & 7 \\
\hline $\begin{array}{c}\text { Total recovered cases after changing } \\
\text { medication }\end{array}$ & 6 & 3 & 7 \\
\hline Percentage of recovered cases & $75 \%$ & $60 \%$ & $100 \%$ \\
\hline
\end{tabular}

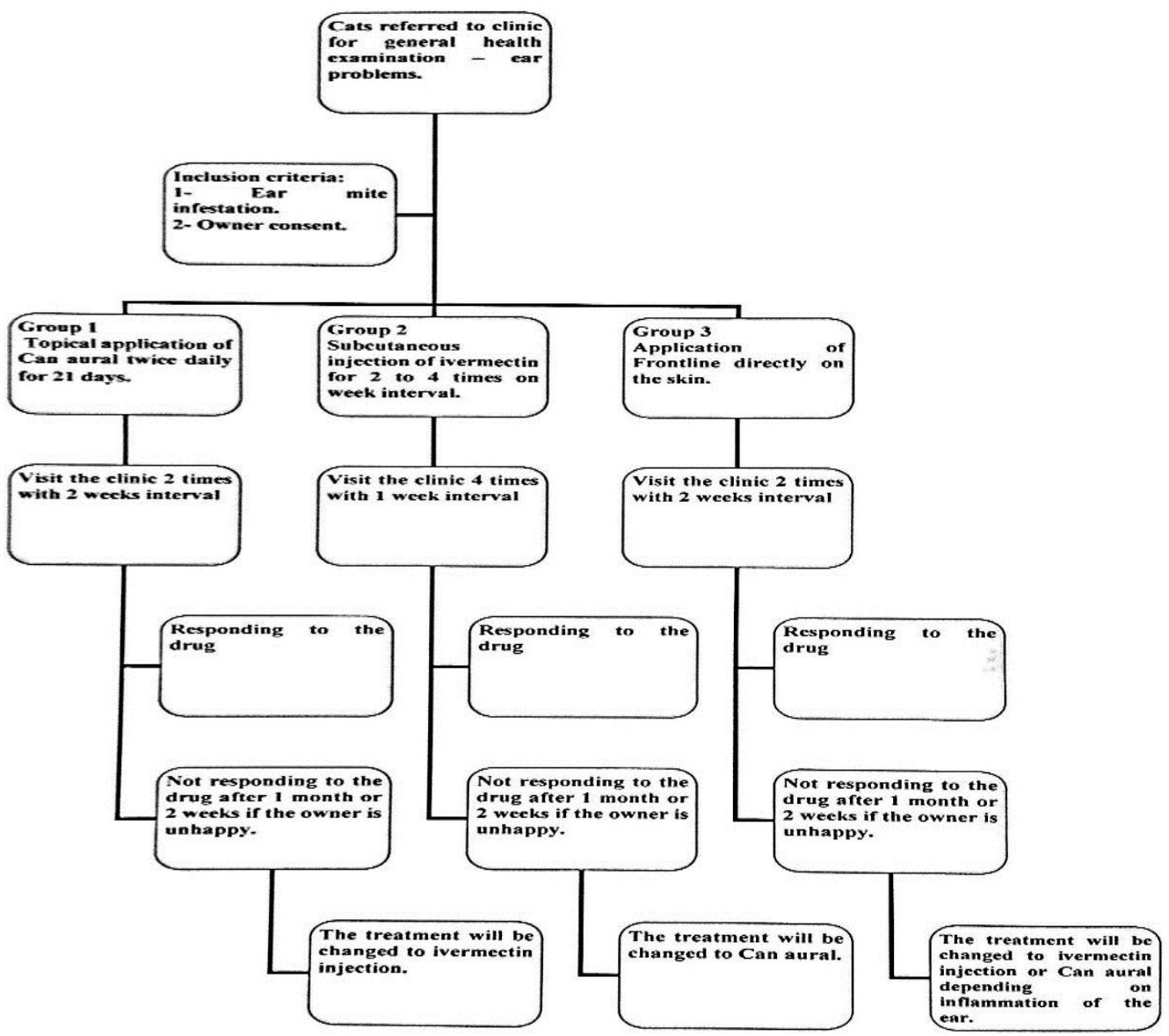

Figure 1: Flow chart of recruited cases

This flowchart show the study protocol started from recruitment of cases, assignment to treatment group, follow up of the cases and evaluation of the case after treatment (Group 1 received ivermectin injection, group 2 received Frontline combo, and group 3 received Canaural ear drops) 
Followup sheet

\begin{tabular}{|l|c|c|c|c|c|c|c|c|c|c|c|}
\hline \multirow{2}{*}{ Signs } & Increased & $\begin{array}{c}\text { No } \\
\text { change }\end{array}$ & \multicolumn{7}{c|}{ Decreased } & Absent \\
\cline { 2 - 10 } & $\mathbf{0}$ & $\mathbf{1}$ & $\mathbf{2}$ & $\mathbf{3}$ & $\mathbf{4}$ & $\mathbf{5}$ & $\mathbf{6}$ & $\mathbf{7}$ & $\mathbf{8}$ & $\mathbf{9}$ & $\mathbf{1 0}$ \\
\hline Itching & & & & & & & & & & & \\
\hline Ear wax & & & & & & & & & & & \\
\hline Hair loss & & & & & & & & & & & \\
\hline Head shaking & & & & & & & & & & & \\
\hline $\begin{array}{l}\text { Ear shaking or } \\
\text { dropping }\end{array}$ & & & & & & & & & & & \\
\hline
\end{tabular}

\begin{tabular}{|c|c|c|c|c|c|c|c|c|c|c|}
\hline \multirow{2}{*}{$\begin{array}{c}\text { Owner } \\
\text { satisfaction }\end{array}$} & Difficult & \multicolumn{7}{|c|}{ To some extent easy } & Easy \\
\cline { 2 - 11 } & 1 & 2 & 3 & 4 & 5 & 6 & 7 & 8 & 9 & 10 \\
\hline $\begin{array}{c}\text { Easy to give the } \\
\text { treatment }\end{array}$ & & & & & & & & & & \\
\hline
\end{tabular}

Figure 2: Follow up sheet

This is the weekly follow-up sheet given to the owner to record the response of their pet to the used medication and ease of administration every week.

\section{Evaluation of the case before starting the treatment:}

\begin{tabular}{|c|c|c|c|}
\hline Degree & Signs & Present & Remarks \\
\hline \multirow{4}{*}{ Mild } & Little amount of ear wax & & \\
\hline & Ear wax is not dark in colour & & \\
\hline & Mild itching at long intervals & & \\
\hline & May see the mite by otoscope & & \\
\hline \multirow{6}{*}{ Moderate } & $\begin{array}{l}\text { Presence of ear wax covering the } \\
\text { ear canal }\end{array}$ & & \\
\hline & \begin{tabular}{|l|} 
Ear wax is dark in colour \\
\end{tabular} & & \\
\hline & Itching at short intervals & & \\
\hline & Loss of hair around the ear & & \\
\hline & $\begin{array}{l}\text { Cat is showing pain during } \\
\text { examination (dropping of ear } \\
\text { and shaking of the head) }\end{array}$ & & \\
\hline & May see the mite by otoscope & & \\
\hline \multirow{6}{*}{ Severe } & Large amount of ear wax & & \\
\hline & Ear wax is dark in colour & & \\
\hline & Severe itching & & \\
\hline & $\begin{array}{l}\text { Loss of hair and may be injures } \\
\text { in the skin around the ear }\end{array}$ & & \\
\hline & $\begin{array}{l}\text { Shaking of the head and } \\
\text { dropping of the ear during and } \\
\text { after the examination for a } \\
\text { period }\end{array}$ & & \\
\hline & $\begin{array}{l}\text { See the mite by otoscope very } \\
\text { easily }\end{array}$ & & \\
\hline \multirow{7}{*}{ Highly severe } & Ear wax blocks the ear canal & & \\
\hline & Ear wax is coffee coloured & & \\
\hline & $\begin{array}{l}\text { Itching and head shaking most of } \\
\text { the time }\end{array}$ & & \\
\hline & $\begin{array}{l}\text { Severe pain and dropping of the } \\
\text { ear all the time }\end{array}$ & & \\
\hline & $\begin{array}{l}\text { Loss of the hair with injuries and } \\
\text { thickening of the skin around the } \\
\text { ear }\end{array}$ & & \\
\hline & Thickening of the ear canal & & \\
\hline & General systemic reaction & & \\
\hline
\end{tabular}

\section{Evaluation of the case after giving the treatment:}

\begin{tabular}{|c|c|c|c|}
\hline \multirow{2}{*}{$\begin{array}{l}\text { The response of the cat to the drug } \\
\text { used. }\end{array}$} & $\begin{array}{c}\mathrm{N}_{0} \\
\text { response }\end{array}$ & To some extent respond & $\begin{array}{l}\text { Complete } \\
\text { response }\end{array}$ \\
\hline & 1 & \begin{tabular}{|l|l|l|l|l|l|l|}
2 & 3 & 4 & 5 & 6 & 7 & 8 \\
\end{tabular} & 10 \\
\hline \multirow[b]{2}{*}{ Recovery of the cat } & $\begin{array}{l}\text { Not } \\
\text { recovered }\end{array}$ & To some extent recovered & $\begin{array}{l}\text { Complete } \\
\text { recovery }\end{array}$ \\
\hline & 1 & \begin{tabular}{|l|l|l|l|l|l|l|}
2 & 3 & 4 & 5 & 6 & 7 & 8 \\
\end{tabular} & 10 \\
\hline \multirow{2}{*}{$\begin{array}{l}\text { To what extent you are satisfied } \\
\text { with this type of treatment? }\end{array}$} & $\begin{array}{c}\text { Not } \\
\text { satisfied }\end{array}$ & To some extent satisfied & $\begin{array}{c}\begin{array}{c}\text { Completely } \\
\text { satisfied }\end{array} \\
\text {. }\end{array}$ \\
\hline & 1 & \begin{tabular}{|l|l|l|l|l|l|l|}
2 & 3 & 4 & 5 & 6 & 7 & 8 \\
\end{tabular} & 10 \\
\hline \multirow{2}{*}{$\begin{array}{l}\text { The appropriateness of the cost of } \\
\text { treatment }\end{array}$} & $\begin{array}{c}\text { Not } \\
\text { appropriate }\end{array}$ & \begin{tabular}{|c|}
$\begin{array}{c}\text { To some extent } \\
\text { appropriate }\end{array}$ \\
\end{tabular} & \begin{tabular}{|l}
$\begin{array}{l}\text { Completely } \\
\text { appropriate }\end{array}$ \\
\end{tabular} \\
\hline & 1 & \begin{tabular}{|l|l|l|l|l|l|l|}
2 & 3 & 4 & 5 & 6 & 7 & 8 \\
\end{tabular} & \begin{tabular}{|l|}
10 \\
\end{tabular} \\
\hline \multirow{2}{*}{$\begin{array}{l}\text { How easy it is to give treatment for } \\
\text { the Full therapeutic period? }\end{array}$} & Hard & To some extent easy & Easy \\
\hline & 1 & \begin{tabular}{|l|l|l|l|l|l|l|}
2 & 3 & 4 & 5 & 6 & 7 & 8 \\
\end{tabular} & 10 \\
\hline \multirow{3}{*}{$\begin{array}{l}\text { How easy is the obligation to give } \\
\text { treatment for Full therapeutic } \\
\text { period? }\end{array}$} & Hard & To some extent easy & Easy \\
\hline & 1 & \begin{tabular}{|l|l|l|l|l|l|l|}
2 & 3 & 4 & 5 & 6 & 7 & 8 \\
\end{tabular} & 10 \\
\hline & & & \\
\hline
\end{tabular}

Figure 3: Sheets for evaluation of cases before and after treatment

The evaluation sheet before treatment was used to assess the severity of ear mite infestation, and the evaluation sheet after treatment was used after completing the course of medication to assess the owner satisfaction with the medication. 
Formatted: Font: $10 \mathrm{pt}$, Complex Script Font: 10 pt

Formatted: Font: 12 pt, Bold Complex Script Font: 12 pt, Bold

Formatted: Font: 12 pt, Bold, Complex Script Font: 12 pt, Bold
Assiut Vet. Med. J. Vol. 61 No. 144 January 2015

\section{Total responded cases to total non- responded cases}

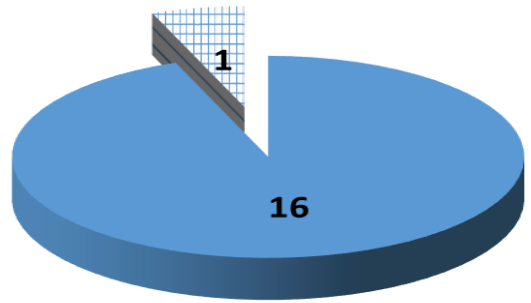

Total responded

+ Total non-responded

Figure 4: Number of total responded case to total non-responded ones.

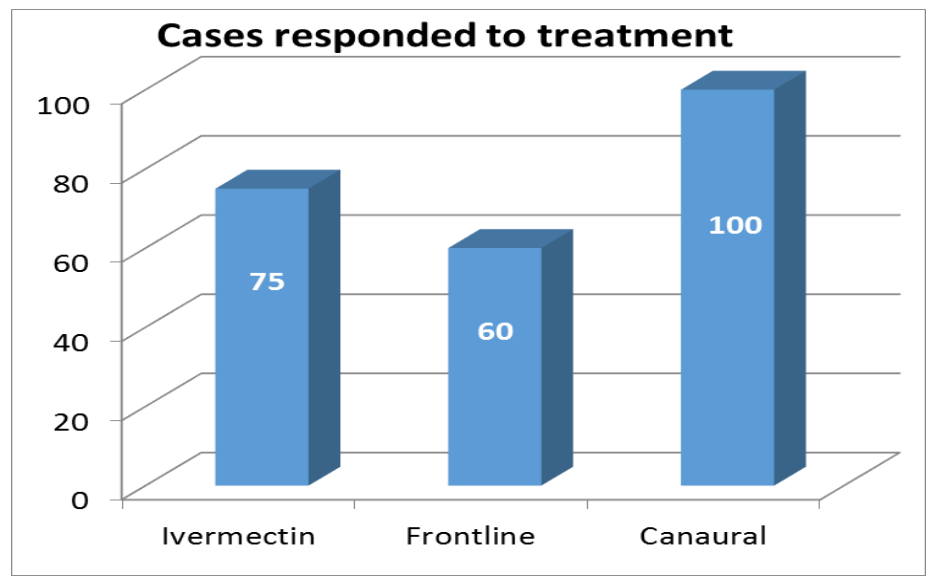

Figure 5: Percentage of cases responded to treatment to recruited cases in each treatment group.

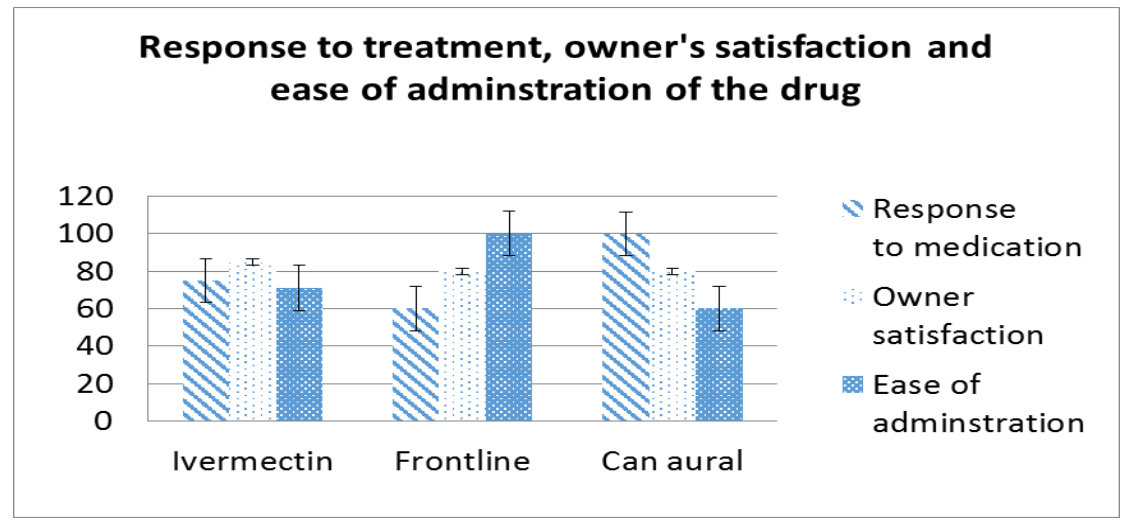

Figure 6: Percentage of cases in relation to response to treatment, owner's satisfaction and ease of administration of the drug, each was calculated to the total number of recruited cases in each treatment group. 


\section{DISCUSSION}

Studies of efficacy of different medications designed to treat ear mite induced otitis externa in cats are very scarce (Germain et al., 2008). In this study, three different medications reported to treat otitis externa and/or ear mite infestation in cats were compared.

Otodectes cynotis is responsible for up to $50 \%$ of the cases of otitis externa seen in practice with an incidence higher than in dogs (Scott et al., 2001). In Egypt, previous report done by Waly and Khallaf (2013) stated that cause of ear inflammation was in $59.21 \%$ of cases due to ear mite infestation. The mite feeds on superficial debris and cerumen, irritates the I ear canal and may cause hypersensitization (Powell et al., 1980) resulting in erythema, ear scratching and a dark, waxy discharge having the classic ground coffee appearance in both ear canals (Scott et al. 2001). Otoacariosis is treated by cleaning the external ear canal and removing debris and discharge, and by multiple instillation of an otic preparation, that contains an acaricide. In addition, a systemic treatment with ivermectin and a topical treatment with fipronil is reported to be effective (Chauve, 1984; Carlotti, 1991; Coleman and Atwell, 1999). This study was designed to evaluate the efficacy of three drugs (ivermectin, fipronil and an Otic preparation contains antibiotic, antifungal and antiinflammatory) used for treatment of ear mites in cats, which one is better to the owner and to the pet.

Over $70 \%$ of cases resolved when treated with ivermectin injections. Ivermectin acts by potentiating the release and effect of GABA (gammaAminobutyric acid), the peripheral neurotansmitter of several parasites. Although in our experience, ivermectin is excellent for treating cases of earmite infestation, it has been reported that other safer treatments are available and injectable ivermectin used for Otodectes is only recommended when other treatments have failed (Ghubash, 2006). However, our clients find the cost and the fact that the medication can be given once a week by the veterinarian is the best option for treatment.

The spot-on treatment we tested resulted in recovery of only $60 \%$ of the cases assigned to that group. The single dosing of Fipronil was preferred initially by owners due to ease of administration. Coleman and Atwell (1999) demonstrated the efficacy of fipronil when was placed directly into each ear canal and applied between the shoulder blades. They found that the same dose given at the entrance of the ear canal had a significant effect on the number of mites than applying it between the shoulder blades, this may explain why the fibronil gave us the lowest percent of response to ear mite infestation. Also Kwochka,
1987; Sosna and Medleau, 1992; Curtis, 1995 and Little, 1996 stated that treatment using topical preparations instilled into the ear canal, together with some form of acricidal therapy applied to the general skin surface to kill mites present outside the ears, has been recommended. However, the success of topical aural treatment alone indicates that the application of acaricide to the entire skin surface may not be essential. The single dosing of fibronil, administrated topically in a single spot to the skin on the animal's back in front of the scapulae either as a single dose or as two doses 1 month apart, facilitates owner compliance with a treatment protocol that's why fibronil give us the highest percent of ease of administration. This in contrast to the otic preparations currently available for the treatment of ear mites, which routinely require application into the ear canal once or twice daily for up to 4 weeks. The animal may strongly resent this procedure, especially when the severity of the otitis results in pain whenever the ears are handled.

All cats treated with Canaural, responded with signs of otitis completely resolving, although there are no clear explanation for killing the mites. One possible reason for the efficacy of this drug may be that the antibiotic or antifungal component of this drug has an undocumented miticidal activity. A further possibility is that the oil/wax base of these preparations may prevent the male mite from coupling with females, thereby hindering copulation and thereby interrupting the life cycle (Scott et al., 1995). 40\% of the owners were dissatisfied with this drug due to the long period of treatment and the difficulty of administering the drug twice a day. This finding agreed with Ghubash (2006) who found that the main disadvantages of these treatments are the need for long-term treatment, patient compliance, and the possibility of reinfestation from the environment. Typically, daily treatment is recommended for a 21 to 30 day. This agrees with our finding.

The total number of cases included in this study was small. However, valuable information was obtained that provides basis for a further more comprehensive study on efficacy of these three medications. A questionnaire -based exploration of owner satisfaction was very informative. Although an otic preparation can be the most effective treatment, the frequency and length of administration can put owner off that choice. This information should be taken into consideration when designing treatments for aural conditions.

\section{CONCLUSION}

In conclusion, although there were no statistically significant difference between the three used medications for treatment of ear mite $(p<0.5)$, Our 
Formatted: Font: $10 \mathrm{pt}$, Complex Script Font: 10 pt

Formatted: Font: Not Bold Complex Script Font: Not Bold

Formatted: Font: 12 pt, Bold Complex Script Font: 12 pt, Bold Formatted: Font: 12 pt, Bold, Complex Script Font: 12 pt, Bold
Assiut Vet. Med. J. Vol. 61 No. 144 January 2015

clinical findings suggest that Canaural is most suitable when otitis externa is present along with ear mite infestation because it gave us $100 \%$ response, and slightly similar percent of owner satisfaction as ivermectin and frontline. Its only problem was the ease of administration. Ivermectin is recommended only if the owner's circumstances will not allow full compliance with Canaural. Frontline Combo is not as effective as the two other medications used in this study so it is not recommended for treating ear mite infestation in spite of its ease of administration or it could be given together with Canaural because cases that did not respond to fibronil we changed it to Canaual and responded well.

\section{REFERENCES}

Carlotti, DN. (1991): Diagnosis and medical treatment of otitis externa in dogs and cats. J. Small Anim. Pract. 32, 394-400.

Chauve, CM. (1984): Traitement parentéral de l'otacariose du chat: efficacité de l'ivermectine. Bull. Soc. Sci. Vet. Comp. 86, 189-198.

Coleman, GT. and Atwell, RB. (1999): Use of fipronil to treat ear mites in cats. Aust. Vet. Pract. 29, 166-168.

Curtis, CF. (1995): Treatment and control of problems associated with parasitic skin surface residents. In: Proceedings of the Royal Veterinary College Dermatology Seminar Ectoparasites and their control, November 1995.

Degiorgis, MP.; Segerstad, CH.; Christensson, B. and Mörner, T. (2001): Otodectic Otoacariasis in Free-Ranging Eurasian Lynx in Sweden. Journal of Wildlife Diseases, 37(3): 626-629.

Germain, P.A.; Grandemange, E. and Bensignor, E. (2008): "Comparison of two topical remedies in treating otitisexterna in cats: A randomized blinded trial." Pratique médicale et chirurgicale de l'animal de compagnie 43: 71-74.

Gubash, R. (2006): Parasitic Miticidal Therapy. In: Clinical Techniques in Small Animal Practice. Elsevier Inc. 135-144.

Gotthelf, LN. (2000): Small Animal Ear Diseases. An Illustrated Guide. W.B. Saunders Company. 88.

Kwochka K.W. (1987): Mites and related disease Vet. Clin. Nort. Am. Small Anim. Pract. 17:1263-1284.
Little, C. (1996): A clinician's approach to the investigation of otitis externa. Practice 18: 9-16.

Powell, MB.; Weisbroth, SH.; Roth, L. and Wilhelmsen. (1980): Reaginic hypersensitivity in Otodectescynotis infestation of cats and mode of mite feeding. Am. J. Vet. Res. 41: 877-882.

Rosser, E.J.,Jr. (2004): Causes of otitis externa. Vet. Clin. North Am. Small Anim. Pract., 34 459-468.

Roy, J.; Bedard, C. and Moreau, M. (2011): Treatment of feline otitis externa due to Otodectes cynotis and complicated by secondary bacterial and fungal infections with Oridermyl auricular ointment. CVJ, Vol. 52, 277-282.

Scott, DW.; Miller, WH. and Griffin, CE. (1995): Parasitic skin disease. In: Scott, DW; Miller, WH and Griffin, CE. Eds. Muller and Kirk's Small Animal Dermatology, 5th ed. Toronto: WB Saunders. 410-412.

Scott, DW.; Miller, WH. and Griffin, CE. (2001): Diseases of eyelids, claws, anal sacs and ears. In: Muller\& Kirk's Small Animal Dermatology, sixth ed. Saunders, Philadelphia, 1185-1235.

Sosna, C.B. and Medleau, L. (1992): External parasites: life cycles, transmission and the pathogenesis of disease. Vet. Med. 6:538-547.

Urquhart, GM.; Armour, J.; Duncan, JL.; Dunn, AM. and Jennings, $F W$. (1996): Veterinary entomology. In: Urquhart, GM; Armour, J; Duncan, JL; Dunn, AM and Jennings, FW (eds.), Veterinary Parasitology, 2nd Edition.Blackwell Scientific Publications, Oxford, pp. 190-201.

Van Den Broek, AHM. and Thoday, KL. (1994): The skin. In Feline Medicine and Therapeutics. $2^{\text {nd }}$ Edition, Chandler, EA; Gaskell, CJ and Gaskell, RM (eds.). Blackwell Science Oxford, UK, 3-83.

Waly, N.E. and Khalaf, M. (2013): "Otitis externa and Otitis media in Cats in Assiut: a Retrospective study of presenting signs, causes, diagnosis and treatment." Assiut Veterinary Medical Journal 59(137): 93-99.

Wills, J. and Wolf, A. (1993): Handbook of Feline Medicine. Pergamon Press Ltd. 312. 


\title{
تقييم الفعالية السريرية لثلاثة أدوية تستعمل في علاج جرب الأذن المسبب لالتهاب الاذن الخارجية في القطط : دراسة أولية
}

\author{
مها /براهيم حامد_؛ رحاب كامل سبي_، نشوى عصدت والمى \\ Email: mahohzero@gmail.com
}

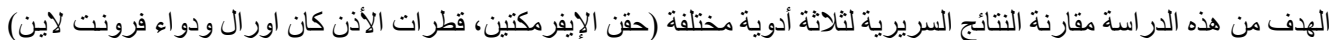

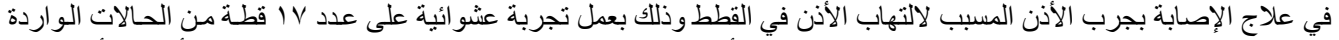

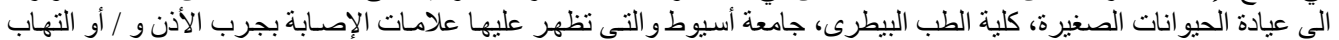

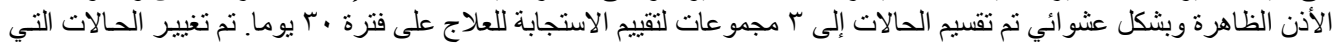

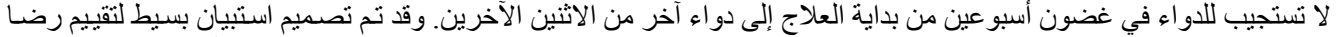

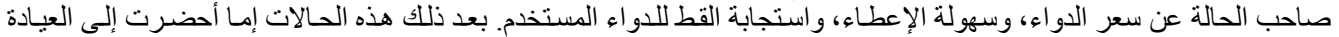

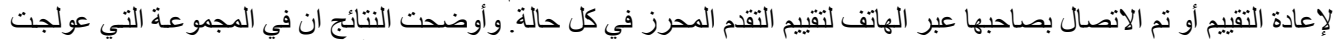

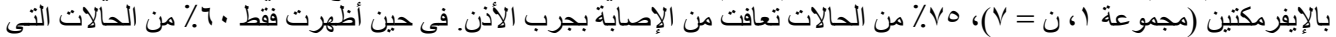

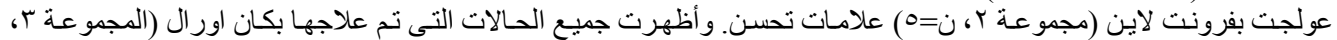

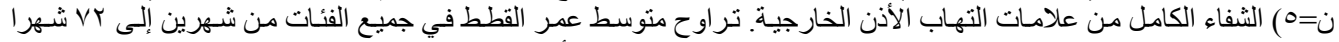

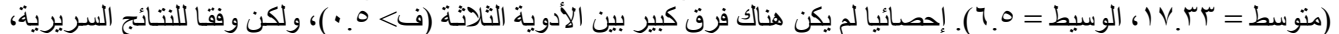

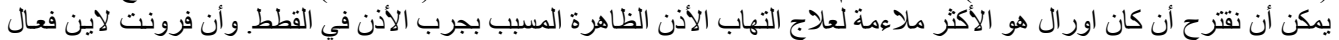
مثل الأدوية الأخرى المستخدمة في هذه الدراسة. 